\title{
Flooding events and rising water temperatures increase the significance of the reed pathogen Pythium phragmitis as a contributing factor in the decline of Phragmites australis
}

\author{
Jan Nechwatal · Anna Wielgoss $\cdot$ Kurt Mendgen
}

\begin{abstract}
Pythium species are economically significant soilborne plant pathogens with worldwide distribution, causing seedling damping-off or root rot diseases. Pythium phragmitis is a newly described pathogen of common reed (Phragmites australis), widespread in the reed-belt of Lake Constance, Germany. It is highly aggressive towards reed leaves and seedlings, but obviously does not affect roots. In the context of 'reed decline' phenomena, P. phragmitis infection of reed inundated during flooding events may be of particular significance. We could show that flooding itself is not necessarily detrimental for reed plants. In the presence of the pathogen, however, most submerged leaves and plants were killed within several weeks. Clipped plants did not show regrowth in the Pythium infested treatments. Significant losses in assimilating leaf area of reeds could, thus, be the result of Pythium infection rather than of flooding alone. Therefore, we suggest that the combination of extended flooding and the presence of $P$. phragmitis might considerably contribute to 'reed decline' at Lake Constance. In parallel, we could
\end{abstract}

Guest editors: K. M. Wantzen, K. O. Rothhaupt, M. Mörtl, M. Cantonati, L. G. Tóth \& P. Fischer

Ecological Effects of Water Level Fluctuations in Lakes

J. Nechwatal $(\bowtie) \cdot$ A. Wielgoss $\cdot$ K. Mendgen

Phytopathology, Universität Konstanz, 78457 Konstanz,

Germany

e mail: jan.nechwatal@uni konstanz.de show that pathogenicity and spread of this species are considerably favoured by rising temperatures. Since an increase in average water temperature has been found for Lake Constance, we propose that $P$. phragmitis could be an important factor in the dieback of reed stands likely to be promoted by predicted climate change phenomena.

Keywords Flooding - Global change .

Oomycetes - Phragmites australis .

Pythium · Zoospores

\section{Introduction}

Common reed (Phragmites australis [Cav.] Trin. ex Steud.), a large perennial grass with worldwide distribution is a major component of wetland and littoral plant communities of many freshwater ecosystems. It usually forms large natural monocultures at the land water interface with several important ecological functions (Haslam, 1972). Within the last decades, dieback of reed stands has been a periodically recurring threat to littoral ecosystems of many European lakes (Ostendorp, 1989; van der Putten, 1997; Brix, 1999). In general, adverse effects of lake water eutrophication, organic acid toxicity, wave action, water level regulation, insect attack, algal mats and low genetic diversity have been repeatedly discussed as possible reasons for the decline (e.g. Ostendorp, 1989; Armstrong et al., 1996; Brix, 1999; 
Koppitz \& Kühl, 2000). Lake Constance, a large prealpine lake and one of Europe's largest inland water bodies, is also affected by the decline, and its reed belt dynamics have been investigated in great detail (e.g. Ostendorp et al., 2003; Dienst et al., 2004). Currently, the negative impact of extreme floods on reed stand health due to impaired oxygen supply of rhizomes and submerged shoots seems to be accepted as one major factor in reed dieback events of Lake Constance (Koppitz, 2004). Thus, the term 'floodinduced reed-dieback' has been introduced by several authors (Ostendorp et al., 2003; Dienst et al., 2004). It is now under discussion in the context of global warming, and of subsequent environmental changes on a more regional scale (Jöhnk et al., 2004). However, other as yet unknown factors have been postulated to account for the damage observed (Ostendorp et al., 2003).

Pythium species are economically significant plant pathogens that cause damage to a large array of different host plants. Grasses and cereals are among the major hosts of this genus (Hendrix \& Campbell, 1973). Being oomycetes, Pythium species are strongly dependent on the presence of water for zoospore dispersal and host plant infection. Pythium phragmitis is a newly described water-borne pathogen of common reed (Nechwatal et al., 2005). It was consistently isolated from soils in permanently flooded parts of Lake Constance reed stands, as well as from other German lacustrine and riverine systems (J. N., unpublished). In in vitro and field assays it proved to be highly aggressive towards seedlings as well as mature leaves of reed. It has been postulated that due to its potential as an aggressive leaf pathogen, $P$. phragmitis might play a significant role in the aetiology of Lake Constance reed decline, in particular under flooding situations (Nechwatal et al., 2005). The aim of this study was to demonstrate in artificial flooding experiments with young $P$. australis plants whether submergence of reed would cause more damage in the presence of the pathogen than would have been caused by flooding alone. Since $P$. phragmitis is known to have a relatively high optimum temperature for growth (Nechwatal et al., 2005) we also wanted to investigate whether warmer temperatures, anticipated consequences of human activity on earth, could possibly favour development and spread of the pathogen. The possible impact of $P$. phragmitis on reed stands, as exemplified by the situation at Lake Constance, is discussed in the light of predicted climate change phenomena and their potential consequences.

\section{Materials and methods}

\section{Flooding experiments}

Reed plants for flooding experiments were grown from commercially available reed seeds (Jelitto Staudensamen, Schwarmstedt, Germany) in autoclaved standard potting soil. After germination, seedlings were transferred singly to plastic pots ( 5 $\mathrm{cm}$ diameter), and grown for 68 weeks in a greenhouse under natural light. By that time plants were approximately $2030 \mathrm{~cm}$ in height, and were beginning to develop additional shoots from their rhizomes. For the tests, plants were chosen, so that within each experiment only largely uniform plants were used. For each treatment within a single experiment, 25 plants were selected. Plants were placed with their pots in 2,000 ml plastic beakers (height approximately $20 \mathrm{~cm}$ ) for subsequent flooding with tap water and Pythium infestation. Pythium phragmitis isolate UKN P40, originally isolated from reed rhizosphere soil of the Lake Constance littoral was grown on V8 agar (Nechwatal et al., 2005) in 90$\mathrm{mm}$ Petri dishes for one day prior to each experiment. Each plant in the Pythium infested treatments received one agar disc (15 $\mathrm{mm}$ diameter) from the growing margin of the $P$. phragmitis culture, spiked on a wooden, autoclaved toothpick which was fixed to the inner wall of the beaker with adhesive tape. Agar discs were mounted so that they were hanging just below water level. Controls received plain agar discs only. In Experiment 1, all plants were fully submerged, i.e. all leaves were in contact with the water. Occasionally, this was achieved by bending leaves down below water level. In Experiment 2, two partial flooding treatments were tested, with approximately 6 and $12 \mathrm{~cm}$ water level, respectively, as measured from the soil surface, corresponding to $50 \%$ and $75 \%$ of the number of plant leaves ( 2 of 4 , or 3 of 4 , respectively). Plant performance and damage was recorded after 4 weeks of inundation, with evaporated water being refilled regularly. All shoots were harvested, measured, and plants left for another 2 weeks to monitor regrowth from the 
rhizomes. In Experiment 3, all plants were clipped right above soil line before the beginning of the test, and subsequently subjected to flooding of approximately 6 and $12 \mathrm{~cm}$ above soil line. Number and length of regrown shoots was recorded after 8 weeks. All experiments were repeated twice.

Pathogenicity test

Pathogenicity tests on mature reed leaves under different temperature regimes were performed as described earlier (Nechwatal et al., 2005). In short, mature leaves from greenhouse grown reed plants were inoculated with $P$. phragmitis by placing a disc (4 $\mathrm{mm}$ diameter) from an actively growing V8 agar culture onto the leaves, and incubated on moist filter paper in Petri dishes at $15,18,20$ and $25^{\circ} \mathrm{C}$. Control leaves received plain V8 agar discs. After 5 days, lesion length was measured. In each test, three different isolates of $P$. phragmitis were used (UKN P13, P42, P52; Nechwatal et al., 2005), with six leaves per isolate. The tests were repeated thrice for each isolate and temperature combination.

\section{Zoospore test}

The influence of temperature on zoospore production of $P$. phragmitis was tested in a bait assay with young reed leaves. Discs from actively growing V8 agar cultures of each of three $P$. phragmitis isolates (UKN $\mathrm{P} 13, \mathrm{P} 42, \mathrm{P} 52)$ were flooded with $60 \mathrm{ml}$ soil extract water (1 1 of water, $10 \mathrm{~g}$ soil, filtered through filter paper) in $100 \mathrm{ml}$ glass beakers. Ten young reed leaf sections (approximately $0.5 \times 0.5 \mathrm{~cm}$ ) were floated on the water surface as baits. Beakers were then incubated at room temperature for approximately $5 \mathrm{~h}$ for initial mycelial growth and sporangia production. Afterwards, they were transferred to 15,20 and $25^{\circ} \mathrm{C}$ chambers and incubated for $24 \mathrm{~h}$ in the dark. Reed baits were removed, and, separately for each isolate and temperature treatment, carefully transferred to Petri dishes containing sterile distilled water, where they were incubated for another $24 \mathrm{~h}$ at room temperature. Number and activity of zoospores present under the different temperature regimes was rated from the number of baits showing signs of infection, i.e. necroses developing from the cut ends of the leaves. For each bait, both cut ends were counted separately, resulting in a maximum number of 20 possible infection sites. The test was repeated thrice for each isolate and temperature combination.

Statistical analysis

Unpaired $t$-tests or one-way ANOVA were performed to test for significant differences among mean values for each treatment in the different experiments. Nonparametric data were log-transformed before analysis. Tukey's Multiple Comparison Test was used as a posttest if one-way ANOVA revealed significant differences between treatments. All statistical analyses were performed using GraphPad Prism 3.00 (GraphPad Software, San Diego, USA).

\section{Results}

In Flooding experiment 1, with full submergence, all shoots of the Pythium infested plants were dead after 4 weeks, while no shoot death occurred in the control plants. Accordingly, shoot dry weight was significantly higher in the control plants (Table 1). None of the Pythium plants showed any regrowth from the rhizomes after two more weeks under non-flooded conditions, indicating complete plant death in the Pythium infested trial. In contrast, all of the control plants showed normal shoot regrowth from the rhizomes, with a mean shoot length of $6.8 \mathrm{~cm}$.

In Experiment 2, plants were only partially flooded, and water levels corresponded to $5075 \%$ of the number of leaves present at the beginning of the experiment. Plant and shoot mortality, although at a low degree only, was found only in the Pythium infested trial. While no difference in mean live shoot length could be observed within the control and Pythium infested plants irrespective of the water level, the latter were significantly shorter as compared to the controls at both $50 \%$ and $75 \%$ submergence (Table 2). The number of live shoots was similar in all treatments, as was mean shoot dry weight (data not shown). Regrowth after 2 weeks of re-exposure was markedly more pronounced in control plants, where $60 \%$ or $75 \%$ of the plants sprouted, as opposed to $42 \%$ and $30 \%$, respectively, in infested plants (Table 2).

When plants were clipped right above soil level before the beginning of the flooding period (Experiment 3), shoot regeneration from the rhizomes after 8 weeks was markedly stronger in control plants which 
Table 1 Flooding experiment 1. Reed plant performance after 4 weeks of full submergence, and two more weeks of regeneration, in the presence or absence of Pythium phragmitis

\begin{tabular}{lll}
\hline & Pythium phragmitis infested $^{\mathrm{a}}$ & Control $^{\mathrm{a}}$ \\
\hline \% Dead shoots & 100 & 0 \\
Shoot dry weight, original shoots $(\mathrm{g})$ & $0.096 \mathrm{a}(0.01)$ & $0.175 \mathrm{~b}(0.02)$ \\
$\%$ Plants with regenerative shoots & 0 & 100 \\
Shoot length, regenerative shoots $(\mathrm{cm})$ & $0(0.0)$ & $6.8(0.8)$ \\
\hline
\end{tabular}

${ }^{a}$ Means and if applicable standard error (SE) of two replicate experiments are given (2 replications $\times 25$ plants). Significant differences $(P \leq 0.01)$ are indicated by different letters (unpaired $t$ test)

Table 2 Flooding experiment 2. Reed plant performance after 4 weeks of partial submergence (50\% or 75\%), and two more weeks of regeneration, in the presence or absence of Pythium phragmitis

\begin{tabular}{|c|c|c|c|c|}
\hline & \multicolumn{2}{|l|}{ P. phragmitis } & \multicolumn{2}{|l|}{ Control } \\
\hline & $50 \%{ }^{\mathrm{a}}$ & $75 \%^{\mathrm{a}}$ & $50 \%^{\mathrm{a}}$ & $75 \%^{\mathrm{a}}$ \\
\hline$\%$ Dead plants & 2 & 10 & 0 & 0 \\
\hline No. of live shoots & $2.78 \mathrm{a}(0.10)$ & $2.40 \mathrm{ac}(0.14)$ & $2.38 \mathrm{bc}(0.07)$ & $2.52 \mathrm{c}(0.10)$ \\
\hline No. of dead shoots & $0.38 \mathrm{a}(0.10)$ & $0.46 \mathrm{a}(0.10)$ & $\mathrm{Ob}$ & $\mathrm{Ob}$ \\
\hline Total no. of shoots & $3.16 \mathrm{a}(0.10)$ & $2.86 \mathrm{ac}(0.12)$ & $2.38 \mathrm{~b}(0.07)$ & $2.52 b c(0.10)$ \\
\hline Shoot length (live shoots) (cm) & $37.3 \mathrm{a}(1.1)$ & 35.8a (1.3) & $42.2 \mathrm{~b}(1.2)$ & $42.7 \mathrm{~b}(1.4)$ \\
\hline$\%$ Plants with regenerative shoots & 42 & 30 & 60 & 75 \\
\hline Shoot length (regenerative shoots) $(\mathrm{cm})$ & $6.6 \mathrm{a}(1.0)$ & 5.1a (1.0) & 6.9a $(1.0)$ & $8.4 \mathrm{a}(0.8)$ \\
\hline
\end{tabular}

${ }^{a}$ Means and if applicable standard error (SE) of two replicate experiments are given ( 2 replications $\times 25$ plants). Significant differences $(P \leq 0.05)$ are indicated by different letters (one way ANOVA, Tukey's Multiple Comparison Test)

produced significantly more shoots (Table 3 ). While some of the control plants even reached above water level from both 6 and $12 \mathrm{~cm}$ depth, none of the infested plants managed to reach this height. Shoots developing from Pythium infested plants were extremely small, and approximately $40 \%$ of the plants were dead (Table 3, Fig. 1). In contrast, none of the control plants had died after 8 weeks of submergence.

Pythium phragmitis proved to be increasingly aggressive to reed leaves with rising temperatures (Fig. 2). Leaf necroses developed fastest at $25^{\circ} \mathrm{C}$, with growth rates similar to those on malt extract agar plates (data not shown). No necroses developed on control leaves.

Similarly, zoospore release rates, and/or zoospore activity of $P$. phragmitis were favoured by warmer temperatures. Reed bait infection was significantly increased at 20 and $25^{\circ} \mathrm{C}$, as compared to $15^{\circ} \mathrm{C}$ (Fig. 3). In none of the tests reed bait infection occurred via vegetative hyphae from the inoculum, as judged from the length of the hyphae emerging from the agar discs.

\section{Discussion}

Morphologically, Phragmites australis is considered a terrestrial plant that secondarily developed specific morphological structures (aerenchyma) to withstand periods of submergence and low oxygen supply (Jackson \& Armstrong, 1999). However, it is generally accepted that reed plants will not be able to tolerate complete flooding for longer periods of time (Mauchamp et al., 2001; Koppitz, 2004). The term 'flood-induced reed dieback' has, therefore, been introduced by several authors to stress the role of flooding events and their consequences like anoxia in the aetiology of reed decline phenomena, in particular at Lake Constance (Ostendorp et al., 2003; Dienst et al., 2004). Our results show that under laboratory conditions, reed plants are able to tolerate periods of major flooding for up to eight weeks, and even will be able to regrow above water level from depths of up to $12 \mathrm{~cm}$ (Table 3), i.e. after being "top submerged" (Mauchamp et al., 2001). Although there still might be some negative effect of submergence on plant 
Table 3 Flooding experiment 3. Clipped reed plant regeneration after 8 weeks of submergence, at two different water depths, in the presence or absence of Pythium phragmitis

\begin{tabular}{|c|c|c|c|c|}
\hline & \multicolumn{2}{|l|}{ P. phragmitis } & \multicolumn{2}{|l|}{ Control } \\
\hline & $6 \mathrm{~cm}^{\mathrm{a}}$ & $12 \mathrm{~cm}^{\mathrm{a}}$ & $6 \mathrm{~cm}^{\mathrm{a}}$ & $12 \mathrm{~cm}^{\mathrm{a}}$ \\
\hline$\%$ Dead plants & 36 & 40 & 0 & 0 \\
\hline No. of shoots (live plants) & $1.81 \mathrm{a}(0.26)$ & $1.60 \mathrm{a}(0.22)$ & $3.72 b(0.26)$ & $3.80 \mathrm{~b}(0.35)$ \\
\hline No. of shoots above water level & $0 \mathrm{a}$ & $0 \mathrm{a}$ & $0.80 \mathrm{~b}(0.16)$ & $0.12 \mathrm{a}(0.07)$ \\
\hline Shoot length (live plants) (cm) & $2.36 \mathrm{a}(0.55)$ & $1.88 \mathrm{a}(0.81)$ & $11.07 \mathrm{~b}(1.62)$ & $11.02 \mathrm{~b}(1.31)$ \\
\hline
\end{tabular}

${ }^{a}$ Means and if applicable standard error (SE) of two replicate experiments are given ( 2 replications $\times 25$ plants). Significant differences $(P \leq 0.01)$ are indicated by different letters (one way ANOVA, Tukey's Multiple Comparison Test)

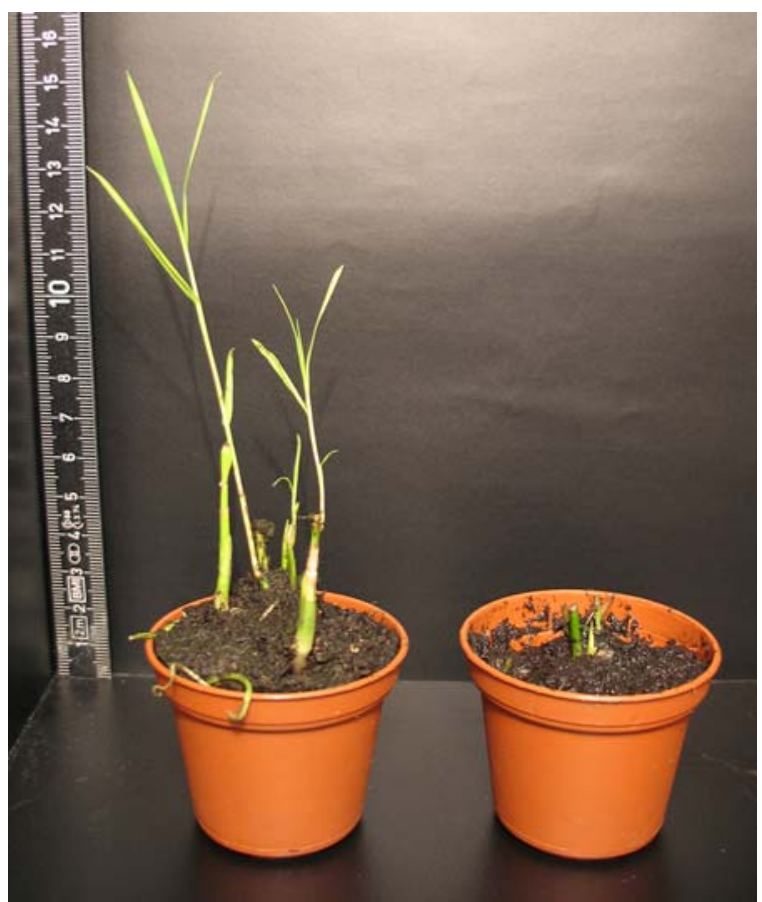

Fig. 1 Flooding experiment 3. Shoot regeneration from reed rhizomes 8 weeks after plants were clipped and flooded to ca. $12 \mathrm{~cm}$ above soil line. Left: uninoculated control, right: Pythium phragmitis inoculated

vitality as compared to non-flooded conditions, as has been reported by Mauchamp et al. (2001), in none of our flooding experiments any of the control plants died, and most plants were able to return to normal growth after being re-exposed to non-flooded conditions. Similarly, in the experiments of Mauchamp et al. (2001), plant mortality was low, and occurred only in permanent and full submergence treatments. In contrast, in the presence of the reed pathogen

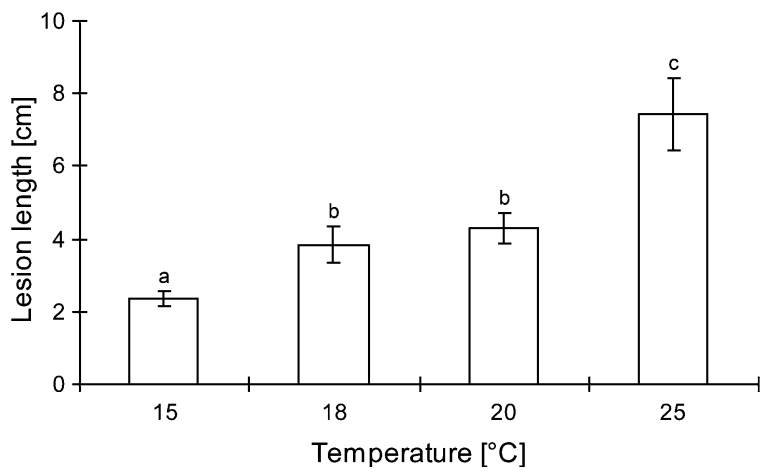

Fig. 2 Lesion size caused by Pythium phragmitis on reed leaves at different temperatures. Means and standard error of three replicate experiments $(3$ replications $\times 3$ isolates $\times 6$ leaves) are given. Different letters above bars indicate significant differences $(P \leq 0.01$, One way ANOVA, Tukey's Multiple Comparison Test)

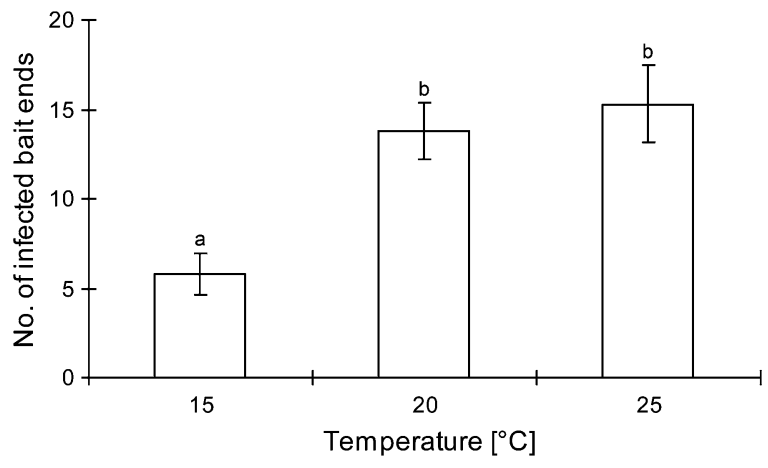

Fig. 3 Zoospore release/activity of Pythium phragmitis as expressed as the number of infected reed leaf bait ends (of a maximum of 20). Means and standard error of three replicate experiments are given ( 3 replications $\times 3$ isolates). Different letters above bars indicate significant differences $(P \leq 0.01$, One way ANOVA, Tukey's Multiple Comparison Test) 
Pythium phragmitis, plant death was common in our tests, in particular when plants were completely submerged, or large parts of the vegetative organs were in contact with water (Table 1). Even only partial submergence occasionally led to plant and shoot mortality, and significantly decreased mean shoot length and regrowth (Table 2). As P. phragmitis obviously is not a root pathogen (J. N., unpublished), and root systems in our tests were usually symptomless (data not shown), infection of reed will generally occur through the leaves. Therefore, we agree on the role of flooding events as an important factor in reed dieback, since only in these situations Pythium zoospores will be able to come into contact with major parts of the susceptible plant organs. However, the hypothesis of 'flood-induced reed dieback' at Lake Constance of Ostendorp et al. (2003), involving low oxygen supply, and anaerobic metabolism under submerged situations as the primary causes for reed plant death is not supported by our data. A direct detrimental effect of flooding on reed plant health could not be observed in our study, supporting the finding that, apart from the presence of aerenchyma, reed shows a certain degree of tolerance to anoxic conditions due to physiological reasons (Brändle \& Crawford, 1987). Indeed, other as yet unknown factors such as insect damage or sediment differences have been postulated to account for the patterns and dynamics of reed damage (Ostendorp et al., 2003). We propose that the observed decline symptoms like stand thinning, change in shoot class composition and stand dieback are in part due to the loss of assimilating leaf area after Pythium infection. Reduced photosynthesis rates might lead to decreasing carbohydrate storage in the rhizomes, and reduced shoot numbers and sizes in the next growing period, as discussed by Nechwatal et al. (2005). In addition, seedling losses due to the pathogen's activity might prevent the re-colonisation of stand gaps, as well as the establishment of new reed stands (Nechwatal et al., 2005). Since $P$. phragmitis has now been isolated from other lakes and riverine systems in Germany (J. N., unpublished), its impact on reed stand dynamics might not be regionally restricted to Lake Constance.

Up to now, inoculum densities of $P$. phragmitis in natural habitats (i.e. zoospore densities in littoral lake water) are not known. Hallet \& Dick (1981) found up to 400 propagules of Pythium spp. with swollen lobulate sporangia (the group which $P$. phragmitis belongs to) per litre lake water in Great Britain. Although $P$. phragmitis does not abundantly sporulate under laboratory conditions (Nechwatal et al., 2005), densities in our tests were most likely higher as compared to natural conditions. However, natural Pythium loads obviously are sufficient to cause infection during natural water level rises even in mature reed leaves in the field. These leaves, even though much more sclerophyllous than those of the seedlings used in our tests, were readily infected with $P$. phragmitis under natural conditions (Nechwatal et al., 2005).

As a consequence of rising mean temperatures on a global scale, an increase in average water temperature of approximately $0.017^{\circ} \mathrm{C}_{\text {year }}{ }^{-1}$ has been found for Lake Constance since the 1960s (Straile et al., 2003). Similar trends were observed in other alpine and prealpine lakes (e.g. Thompson et al., 2005). In parallel, dieback of reed belts also has been reported from many European lakes for about five decades (Ostendorp, 1989; Van der Putten, 1997; Brix, 1999; Ostendorp et al., 2003). Since $P$. phragmitis has an optimum growth temperature of around $30^{\circ} \mathrm{C}$ (Nechwatal et al., 2005), the species might be considerably favoured by higher mean water temperatures in long-term considerations, thus causing a higher incidence of reed damage. Our results indeed show that zoospore production and virulence of $P$. phragmitis on mature reed leaves significantly increases with rising temperature. Leaf infection exhibited spread rates similar to the pathogen's growth rates on agar media (Fig. 2), indicating that a maximum will be reached at $30^{\circ} \mathrm{C}$, with a subsequent decline to $40^{\circ} \mathrm{C}$, the maximum temperature for growth (Nechwatal et al., 2005). Zoospore production and release, although generally considered to be favoured by chilling in many Pythium spp. (Martin, 1992), also increased with rising temperature (Fig. 3). The potential bias brought about by faster growth of germinating zoospores and subsequent secondary hyphal infection of baits at higher temperatures was counteracted by our experimental setup. Thus, our results indicate that differences in leaf bait infection in the tests were basically due to the influence of temperature on zoospore production and release.

Continuous temperature measurements in the eulittoral zone (water/sediment) of Lake Constance indicate that optimum infection temperatures above $20^{\circ} \mathrm{C}$ will be reached during summertime from June to September (J. N., unpublished). Since Lake Constance is a largely unregulated lake with natural 
water regimes, flooding events will most likely occur during summertime, after snow melt in the Alpine region, and thus, coincide with optimal temperatures for zoospore production and infection. It, therefore, can be concluded that global change phenomena via rising mean water temperatures potentially promote Pythium infection of $P$. australis during summer flooding events, since the pathogen is considerably favoured by higher temperatures within the range of $2030^{\circ} \mathrm{C}$. A similar promotion of the important oomycete root pathogen Phytophthora cinnamomi by rising mean temperatures in Europe has been suggested by Brasier \& Scott (1994).

Remarkably, out of 17 oomycete species isolated during 2003 from Lake Constance littoral sites, nine had temperature optima of $30^{\circ} \mathrm{C}$ and above (J. N., A. W. \& K. M., unpublished), among them another new species of Pythium and a previously undescribed Phytophthora sp. (Nechwatal \& Mendgen, 2006a, b). In contrast, in a large-scale field study from the late 1960s and early 1970s from The Netherlands (van der Plaats-Niterink, 1975) only 3 out of 19 identified Pythium spp. from similar sites had an optimum growth temperature of $\geq 30^{\circ} \mathrm{C}$. Although nothing is known about the past composition of oomycete communities at our sites, these findings could point at a recent gradual shift in community composition towards high-temperature species, possibly brought about by recent climate change phenomena.

Acknowledgement This study was funded by the Deutsche Forschungsgemeinschaft (DFG), as part of the SFB 454 ('Littoral Zone of Lake Constance').

\section{References}

Armstrong, J., F. Afreen Zobayed \& W. Armstrong, 1996. Phragmites die back: sulphide and acetic acid induced bud and root death, lignifications, and blockages within aeration and vascular systems. New Phytologist 134: 601614.

Brändle, R. \& R. M. M. Crawford, 1987. Rhizome anoxia tolerance and habitat specialization in wetland plants. In Crawford, R. M. M. (ed.), Plant Life in Aquatic and Amphibious Habitats. Blackwell, Oxford: 397410.

Brasier, C. M. \& J. K. Scott, 1994. European oak declines and global warming: a theoretical assessment with special reference to the activity of Phytophthora cinnamomi. EPPO Bulletin 24: 221232.

Brix, H., 1999. The European research project on reed die back and progression (EUREED). Limnologica 29: 510.
Dienst, M., K. Schmieder \& W. Ostendorp, 2004. Dynamik der Schilfröhrichte am Bodensee unter dem Einfluß von Wasserstandsvariationen. Limnologica 34: 2936.

Hallet, I. C. \& M. W. Dick, 1981. Seasonal and diurnal fluc tuations of oomycete propagule numbers in the free water of a freshwater lake. Journal of Ecology 69: 671 692.

Haslam, S. M., 1972. Biological flora of the British Isles: Phragmites communis Trin. (Arundo phragmites L.,? Phragmites australis (Cav.) Trin. ex Steudel). Journal of Ecology 60: 585610.

Hendrix, F. F. \& W. A. Campbell, 1973. Pythiums as plant pathogens. Annual Review of Phytopathology 11: 7798.

Jackson, M. B. \& W. Armstrong, 1999. Formation of aeren chyma and the processes of plant ventilation in relation to soil flooding and submergence. Plant Biology 1: 274287.

Jöhnk, K. D., D. Straile \& W. Ostendorp, 2004. Water level variability and trends in Lake Constance in the light of the 1999 centennial flood. Limnologica 34: 1521.

Koppitz, H., 2004. Effects of flooding on the amino acid and carbohydrate patterns of Phragmites australis. Limno logica 34: 3747.

Koppitz, H. \& H. Kühl, 2000. To the importance of genetic diversity of Phragmites australis in the development of reed stands. Wetlands Ecology and Management 8: 403414.

Martin, F. N., 1992. Pythium. In Singleton, L. L., J. D. Mihail \& C. M. Rush (eds), Methods for Research on Soilborne Phytopathogenic Fungi. APS Press, St. Paul, Minnesota: 3949.

Mauchamp, A., S. Blanch \& P. Grillas, 2001. Effects of sub mergence on the growth of Phragmites australis seedlings. Aquatic Botany 69: 147164.

Nechwatal, J. \& K. Mendgen, 2006a. Pythium litorale sp. nov., a new species from the littoral of Lake Constance, Ger many. FEMS Microbiology Letters 255: 96101.

Nechwatal, J. \& K. Mendgen, 2006b. Widespread detection of Phytophthora taxon Salixsoil in the littoral of Lake Constance, Germany. European Journal of Plant Patho logy 114: 261264.

Nechwatal, J., A. Wielgoss \& K. Mendgen, 2005. Pythium phragmitis sp. nov., a new species close to $P$. arrhe nomanes as a pathogen of common reed (Phragmites australis). Mycological Research 109: 13371346.

Ostendorp, W., 1989. 'Die back' of reeds in Europe a critical review of literature. Aquatic Botany 35: 526.

Ostendorp, W., M. Dienst \& K. Schmieder, 2003. Disturbance and rehabilitation of lakeside Phragmites reeds following an extreme flood in Lake Constance (Germany). Hydro biologia 506 509: 687695 .

Straile, D., K. Jöhnk \& H. Rossknecht, 2003. Complex effects of winter warming on the physicochemical characteristics of a deep lake. Limnology and Oceanography 48: 14321438.

Thompson, R., C. Kamenik \& R. Schmidt, 2005. Ultra sensi tive Alpine lakes and climate change. Journal of Limnology 64: 139152.

Van der Plaats Niterink, A. J., 1975. Species of Pythium in the Netherlands. Netherlands Journal of Plant Pathology 81: 2237.

Van der Putten, W. H., 1997. Die back of Phragmites australis in European wetlands: an overview of the European research programme on reed die back and progression (1993 1994). Aquatic Botany 59: 263275. 